\title{
Activity concentrations of primordial radionuclides in sediments of surface - water dams in southwest Nigeria - a baseline survey
}

\author{
M.O. ISINKAYE ${ }^{1}$, I.P. FARAI ${ }^{2}$
}

(Manuscript received 21 March 2008, accepted 2nd June 2008)

\begin{abstract}
The radionuclide contents of sediment samples collected from 20 surface-water dams in southwestern Nigeria have been determined by low-level gamma-spectroscopy. The average concentration of ${ }^{40} \mathrm{~K}$ in each of the dams varied between $110.9 \pm$ $11.9 \mathrm{~Bq} \mathrm{~kg}^{-1}$ and $1025.9 \pm 36.8 \mathrm{~Bq} \mathrm{~kg}^{-1}$ with an overall mean $( \pm \mathrm{SD})$ of $549.3 \pm$ $247.6 \mathrm{~Bq} \mathrm{~kg}{ }^{-1}$ while that of ${ }^{238} \mathrm{U}$ varied from $17.1 \pm 3.6$ to $51.9 \pm 8.7 \mathrm{~Bq} \mathrm{~kg}^{-1}$ with an overall mean $( \pm \mathrm{SD})$ of $27.6 \pm 8.5 \mathrm{~Bq} \mathrm{~kg}^{-1}$ and that of ${ }^{232} \mathrm{Th}$ varied from $26.2 \pm$ $3.6 \mathrm{~Bq} \mathrm{~kg}{ }^{-1}$ to $130.1 \pm 23.7 \mathrm{~Bq} \mathrm{~kg}^{-1}$ with overall mean $( \pm S D)$ of $62.0 \pm 26.1 \mathrm{~Bq} \mathrm{~kg}^{-1}$. The variability of the values shows the wide disparity in the measured activity concentrations. The mean radium equivalent of $158.9 \mathrm{~Bq} \mathrm{~kg}^{-1}$ was calculated for the sediments in the dams. No artificial gamma emitting radionuclide was detected in the samples.
\end{abstract}

Keywords: Activity concentration / sediment / surface-water dam / radium equivalent activity / southwest Nigeria

RÉSUMÉ Concentrations des activités des radionucléides primordiaux dans les sédiments des retenues des eaux de ruissellement dans le sud-ouest du Nigéria. Étude de référence.

Les teneurs en radionucléide des échantillons de sédiment collectés dans 20 barrages d'eaux de ruissellement au sud ouest du Nigéria ont été déterminées par la gammaspectroscopie. La concentration moyenne de ${ }^{40} \mathrm{~K}$ dans chacun des barrages varie entre $110,9 \pm 11,9 \mathrm{~Bq} \mathrm{~kg}^{-1}$ et $1025,9 \pm 36,8 \mathrm{~Bq} \mathrm{~kg}^{-1}$ avec un moyenne globale $( \pm \mathrm{SD})$ de $549,3 \pm 247,6 \mathrm{~Bq} \mathrm{~kg}^{-1}$ tandis que celle de ${ }^{238} \mathrm{U}$ variait de $17,1 \pm 3,6$ à $51,9 \pm$ $8,7 \mathrm{~Bq} \mathrm{~kg}^{-1}$ avec un moyenne globale $( \pm \mathrm{SD})$ de $27,6 \pm 8,5 \mathrm{~Bq} \mathrm{~kg}^{-1}$ et celle de ${ }^{232} \mathrm{Th}_{\mathrm{de}}$ $26,2 \pm 3,6 \mathrm{~Bq} \mathrm{~kg}^{-1}$ à $130,1 \pm 23,7 \mathrm{~Bq} \mathrm{~kg}^{-1}$ avec une moyenne globale $( \pm$ SD) de $62,0 \pm$ $26,1 \mathrm{~Bq} \mathrm{~kg}{ }^{-1}$. La grande dispersion des incertitudes montre la grande disparité des concentrations mesurées. L'équivalent moyen en radium de $158,9 \mathrm{~Bq} \mathrm{~kg}^{-1}$ a été calculé pour tous les sédiments collectés. Aucun radionucléide émetteur gamma artificiel n'a été détecté dans les échantillons.

\section{Introduction}

The major source of radionuclides in lakes and dams is the weathering of potassium, thorium and uranium-bearing rocks and the subsequent transportation

Department of Physics, University of Ado-Ekiti, P.M.B 5363, Ado-Ekiti, Nigeria.

2 Department of Physics, University of Ibadan, Nigeria. 
of these rock fragments by runoffs from highlands. Apart from weathering, naturally occurring radionuclides can be discharged into the aquatic environment through various human and industrial activities such as application of phosphate fertilizer in surrounding farmlands, disposal of domestic wastes and sewages into streams and rivers, discharge of industrial waste effluent directly or indirectly into rivers, mining of uranium etc.

Lakes and dams receive water from rivers, run-off and rainfall. Therefore, the radioactive mineral content of a lake will depend on the mineralogical composition of the catchment areas and the chemistry $(\mathrm{pH}$, organic content and redox) of the rivers that flow into the lake. When hydrophobic organic contaminants enter a water body, they are attached to the particulate matter. This particulate matter then settles and accumulates in the bottom sediments. Consequently, sediment serves either as a sink or as a temporary repository for radioactive contaminants. Under certain conditions, the contaminants in the sediments may be released back into water and enter the food chain (IAEA, 2003a).

In southwest Nigeria, many factories are located on river banks and use the various rivers as open sewers for their effluents. Prior to year 2001, when the Nigeria Nuclear Regulatory Authority (NNRA) came into existence, there was virtually no control of nuclear materials and wastes. Some of these factories, which use radioactive materials in their process flow, could have disposed the wastes, which may contain radioactive substances into the rivers. This may pose a high risk to the environment, if such disposal is done on large scale. Hence, the need to evaluate the concentrations of radionuclides in lakes formed by these rivers.

Many dams and water supply projects are constructed and operated in southwest Nigeria, to meet human needs. The first dam in the region was constructed in 1942. Most of the dams apply convectional water treatment methods. These methods are known to effectively remove a greater percentage of radionuclides from natural water (USEPA, 2007).

A good knowledge of the natural radioactivity levels of sediments is essential for a correct assessment of the degree of pollution. Some radiometric survey had been carried out on soil, rocks, refuse dump sites and building materials (Farai and Jibiri, 2000; Ajayi, 2000; Isinkaye and Faweya, 2006; Farai and Ademola, 2005) in the study area. However, data are presently very scanty on the concentration of radionuclides in rivers, surface-water dams, lakes and tap water in the region and indeed Nigeria. The present study is aimed at providing a baseline data on the distribution of natural radionuclides in the artificial lakes for water supply in the southwestern Nigeria using gamma-ray spectrometry. 


\section{Materials and methods}

\subsection{Sampling}

The study area is located between latitude $5^{\circ} 28^{\prime}$ and $8^{\circ} 30^{\prime} \mathrm{N}$ and longitude $3^{\circ} 22^{\prime}$ and $5^{\circ} 46^{\prime} \mathrm{E}$. This area like most parts of Nigeria is characterized by two distinct climatic seasons, namely the dry season from December to March and the wet season from April to November. The annual rainfall in the region is about $3500 \mathrm{~mm}$. The area is also characterized by hilly topography; the hills are developed over the basement complex with their elevations ranging from $300 \mathrm{~m}$ to $600 \mathrm{~m}$ above sea level. The region is well drained. Prominent among the rivers are River Ogun, River Oyan, River Owena, River Osse, River Shasha, River Osun, River Ero etc. Most of these rivers flow across the basement complex cutting down to the hard metamorphic rocks and then cross the sedimentaries to the Atlantic Ocean.

Surface layer sediments were collected from twenty surface-water dam sites listed in Table I. The locations of the dams in the map of southwest Nigeria is presented in Figure 1. A total of two hundred and seven (207) sediment samples were collected for spectrometric analysis. The number of samples collected from each of the dams varied from five to fifteen, depending on the size of the dam. They were collected randomly from different points within the lake of each dam, with the help of local fishermen. The sampled points could not be spaced out in a regular grid as a lot depended on the judgment and convenience of the fishermen. Efforts were however made to collect samples from different sediment formations in the lakes. The composition of the collected sediments include; fine-grain sand, gravel, sandy-clay, muddy-sand, muddy-clay and mud.

\subsection{Sample preparation and measurement}

For the purpose of gamma-ray spectrometric analysis, the samples were air-dried for between 2-4 days, pulverized and homogenized. The pulverized samples were then oven-dried at $105{ }^{\circ} \mathrm{C}$ until they attained constant weight. Three hundred grams (300 g) of each dried sample was sealed in radon impermeable, cylindrical plastic containers $(8 \mathrm{~cm}$ height and $7.5 \mathrm{~cm}$ diameter). The samples were then stored for upward of 1 month before counting, so as to ensure radioactive equilibrium between the long-lived radionuclides and their short-lived decay products. The storage of the samples for this period is essential, because the activities of ${ }^{238} \mathrm{U}$ and ${ }^{232} \mathrm{Th}$ were measured by estimating ${ }^{214} \mathrm{Bi}$ and ${ }^{208} \mathrm{Tl}$ respectively (Singh et al., 2003). Radiometric measurements were carried out, using a gamma-ray detection system consisting of a $7.6 \mathrm{~cm} \times 7.6 \mathrm{~cm} \mathrm{NaI}(\mathrm{Tl})$ detector (Canberra, model: 802 series). The detector was coupled to a Canberra series 10 plus multi channel 
TABLE I

The location, river source and the number of samples collected from each of the dams. Emplacement des fleuves et numéros d'échantillons collectés pour chaque retenue.

\begin{tabular}{|c|c|c|c|c|c|}
\hline State & Code & Name of dam & Location & River source & No of samples collected \\
\hline \multirow[t]{3}{*}{ Ondo } & 1 & Awara & Ikare & River Asanodi & 10 \\
\hline & 2 & Osse & Owo & River Osse & 10 \\
\hline & 3 & Owena & Owena & River Owena & 12 \\
\hline \multirow[t]{4}{*}{ Ekiti } & 4 & Egbe & Egbe-Ekiti & Little Osse River & 11 \\
\hline & 5 & Ureje & Ado-Ekiti & River Ureje & 05 \\
\hline & 6 & Itapaji & Itapaji-Ekiti & River Ele & 10 \\
\hline & 7 & Ero & Ikun-Ekiti & River Ero & 10 \\
\hline \multirow[t]{6}{*}{ Osun } & 8 & Ijebu-Ijesha & Esa-Odo & River Osun & 10 \\
\hline & 9 & Eko-Ende & Eko-Ende & Otin River & 11 \\
\hline & 10 & Okinni & Oba Village & River Erinle & 14 \\
\hline & 11 & Old Ede & Ede & River Erinle & 15 \\
\hline & 12 & Iwo & Iwo & River Aiba & 12 \\
\hline & 13 & Opa & OAU, Ife & Opa River & 07 \\
\hline \multirow[t]{5}{*}{ Oуо } & 14 & Asejire & Ibadan & River Osun & 14 \\
\hline & 15 & Awba & UI, Ibadan & River Awba & 05 \\
\hline & 16 & Eleyele & Ibadan & River Ona & 10 \\
\hline & 17 & Оуо & Oуо & River Awon & 10 \\
\hline & 18 & Eruwa & Eruwa & River Opeki & 11 \\
\hline \multirow[t]{2}{*}{ Ogun } & 19 & Lekan Are & Abeokuta & River Are & 10 \\
\hline & 20 & Oyan & Abeokuta & River Oyan & 10 \\
\hline
\end{tabular}

analyser (MCA) (Model: 1104) through a pre-amplifier base. The detector has a resolution of about $8 \%$ at $0.662 \mathrm{keV}$ line of ${ }^{137} \mathrm{Cs}$.

A sediment sample (IAEA-315), with matrix similar to the pulverized samples was used for the efficiency calibration of the system. The same geometry was used for both the samples and the reference material. The counting time for all measurements was $36,000 \mathrm{~s}(10 \mathrm{hrs})$. The intensities of the gamma lines $1.465 \mathrm{MeV}$ of ${ }^{40} \mathrm{~K}, 1.764 \mathrm{MeV}$ of ${ }^{214} \mathrm{Bi}$ and $2.641 \mathrm{MeV}$ of ${ }^{208} \mathrm{Tl}$ were used to determine the activity concentrations of ${ }^{40} \mathrm{~K},{ }^{238} \mathrm{U}$ and ${ }^{232} \mathrm{Th}$, respectively (Chiozzi et al., 2000; IAEA, 2003b). 


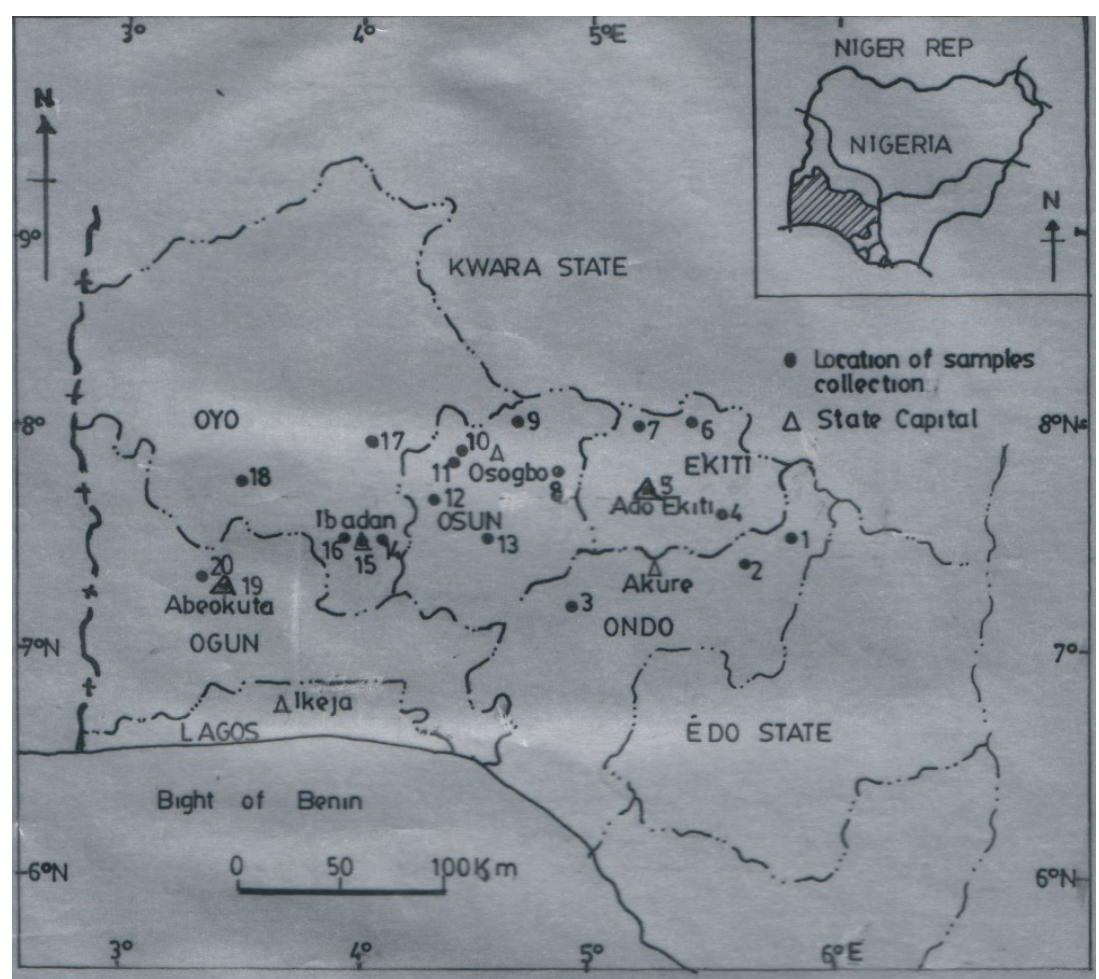

Figure 1 - Map of southwestern Nigeria showing the locations of samples collection.

Carte du sud-ouest nigerian montrant la localisation des collectes d'échantillons.

The minimum detectable activity (MDA) of the measurement system was calculated using the formula given by USDOE (1992) as:

$$
\mathrm{MDA}=4.65 \sigma_{\mathrm{B}} f
$$

where the MDA is at $5 \%$ confidence level, $\sigma_{\mathrm{B}}$ is the standard deviation of the background counts in the region of interest, and $f$ is the factor used to convert count rate to activity which include consideration of mass, counting efficiency, emission probability and counting time. The MDA was estimated to be 24.6, 6.2 and $9.1 \mathrm{~Bq} \mathrm{~kg}{ }^{-1}$ for ${ }^{40} \mathrm{~K},{ }^{226} \mathrm{Ra}\left({ }^{238} \mathrm{U}\right)$ and ${ }^{232} \mathrm{Th}$, respectively. All activity concentrations below the MDA were regarded as below the detection limit (BDL) of the measuring system. 


\section{Results and discussion}

The activity concentrations of radionuclides measured in sediment samples from the twenty surface-water dams in southwest Nigeria are presented in Table II. The concentrations of ${ }^{40} \mathrm{~K},{ }^{238} \mathrm{U}$ and ${ }^{232} \mathrm{Th}$ in all the sediment samples are in the ranges: BDL-1653.9, BDL-276.7 and BDL-188.5 Bq kg-1, respectively. The mean concentrations of ${ }^{40} \mathrm{~K},{ }^{238} \mathrm{U}$ and ${ }^{232} \mathrm{Th}$ were calculated for each of the dams. The highest mean value for ${ }^{40} \mathrm{~K}\left(1025.9 \pm 36.8 \mathrm{~Bq} \mathrm{~kg}^{-1}\right)$ was obtained in Itapaji dam (Ekiti State) while the lowest value $\left(110.9 \pm 9.7 \mathrm{~Bq} \mathrm{~kg}^{-1}\right)$ was obtained in Asejire dam (Oyo State). The mean values of ${ }^{238} \mathrm{U}$ varied between $17.1 \pm 3.6 \mathrm{~Bq} \mathrm{~kg}^{-1}$ in Ureje dam (Ekiti State) and $51.9 \pm 8.7 \mathrm{~Bq} \mathrm{~kg}^{-1}$ in Eko-Ende dam (Osun State). For ${ }^{232} \mathrm{Th}$, the mean concentration in each of the dams ranged from $26.2 \pm 3.6 \mathrm{~Bq} \mathrm{~kg}^{-1}$ in Oyo dam (Oyo State) to $130.1 \pm 23.7 \mathrm{~Bq} \mathrm{~kg}^{-1}$ in Ureje dam (Ekiti State).

The ranges and mean concentrations obtained in the sediments from each of the dams surveyed in this study are consistent with the ranges and mean values measured in rocks and soil samples from different parts of the region by other researchers (Farai and Jibiri, 2000; Ajayi, 2000; Fasasi et al., 1999). The high level of ${ }^{40} \mathrm{~K}$ concentrations is associated with the granitic rocks, which is a common feature of the study area. In previous studies, Farai and Jibiri (2000) reported mean concentrations of $222 \pm 169,39 \pm 17$ and $75 \pm 64 \mathrm{~Bq} \mathrm{~kg}^{-1}$ for ${ }^{40} \mathrm{~K},{ }^{238} \mathrm{U}$ and ${ }^{232} \mathrm{Th}$ respectively in top soil samples from Ibadan (Oyo State). Fasasi et al. (1999) also reported mean concentrations of $114.40 \pm 47.06,18.79 \pm 9.89$ and $13.92 \pm$ $5.83 \mathrm{~Bq} \mathrm{~kg}^{-1}$ for ${ }^{40} \mathrm{~K},{ }^{226} \mathrm{Ra}\left({ }^{238} \mathrm{U}\right)$ and ${ }^{228} \mathrm{Ac}\left({ }^{232} \mathrm{Th}\right)$ respectively in agricultural soil in Ile-Ife (Osun State) while Ajayi (2000) reported a mean concentration of $1203.1 \pm 687.2 \mathrm{~Bq} \mathrm{~kg}^{-1}$ for ${ }^{40} \mathrm{~K}, 57.9 \pm 28.1 \mathrm{~Bq} \mathrm{~kg}^{-1}$ for ${ }^{238} \mathrm{U}$ and $81.6 \pm$ $23.8 \mathrm{~Bq} \mathrm{~kg}^{-1}$ for ${ }^{232} \mathrm{Th}$ in rock samples from Ikogosi (Ekiti State). It can then be assumed that the sediment samples have potassium, uranium and thorium contents similar to those of rocks and soil of the study area.

The overall arithmetic mean concentration was calculated for each of the radionuclides detected in this study. The means, as shown in Table II are $549.3 \pm$ 247.6, $27.9 \pm 8.5$ and $62.0 \pm 26.1 \mathrm{~Bq} \mathrm{~kg}^{-1}$ for ${ }^{40} \mathrm{~K},{ }^{238} \mathrm{U}$ and ${ }^{232} \mathrm{Th}$, respectively. The reported uncertainty is the standard deviation which shows the spread of activity concentration in the region. Table III gives the comparison in the ranges and the mean concentrations found in this survey with ranges and means in other locations of the world. The activity concentrations of ${ }^{40} \mathrm{~K},{ }^{238} \mathrm{U}$ and ${ }^{232} \mathrm{Th}$ obtained in this survey are typical of uncontaminated sediments in different parts of the world.

The distribution of the natural radionuclides in the sediment samples is not uniform. In order to evaluate the total exposure to radiation caused by ${ }^{40} \mathrm{~K},{ }^{226} \mathrm{Ra}$ $\left({ }^{238} \mathrm{U}\right)$ and ${ }^{232} \mathrm{Th}$ in the sediment samples, the activity concentrations of these 
ACTIVITY CONCENTRATIONS OF PRIMORDIAL RADIONUCLIDES IN SEDIMENTS

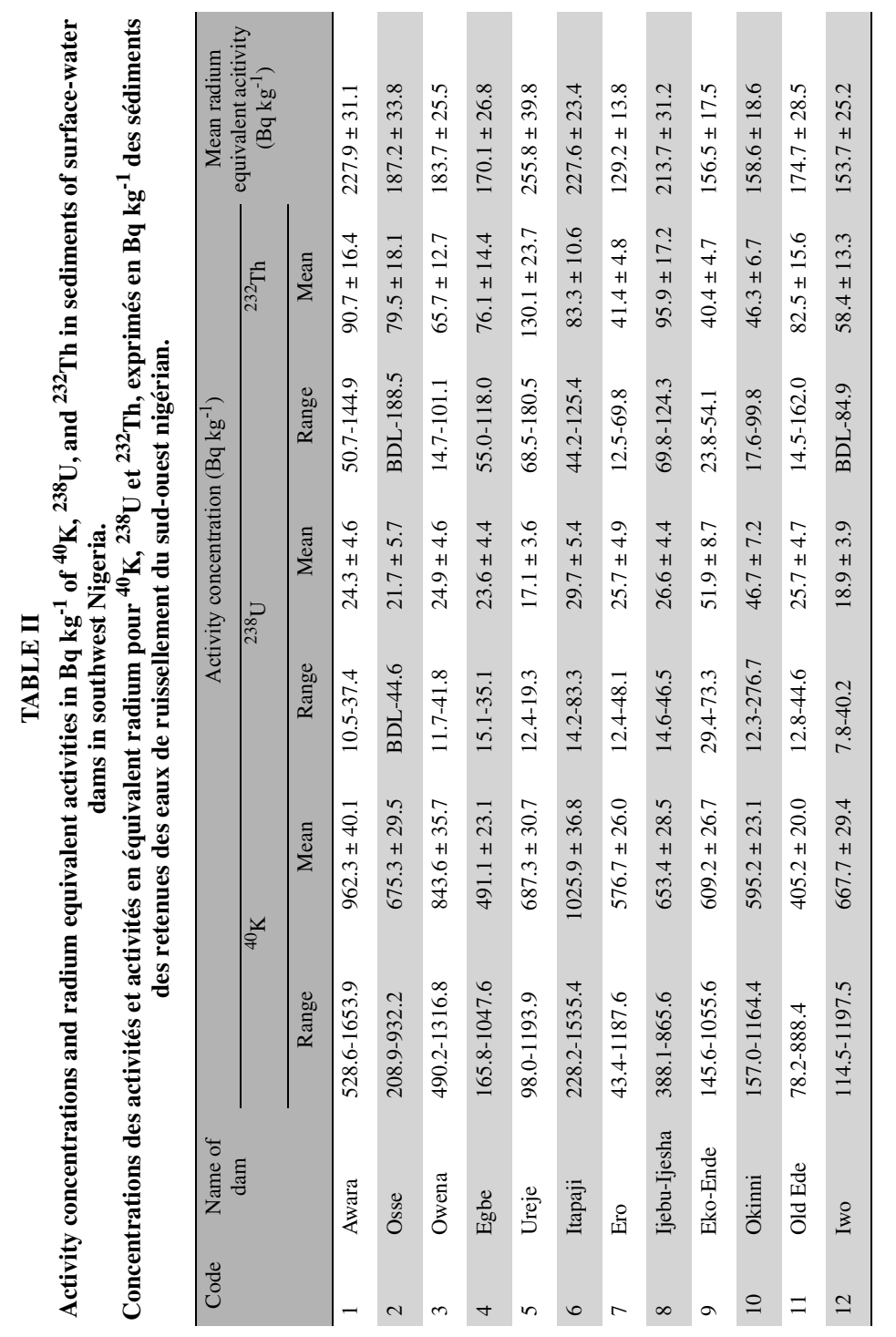




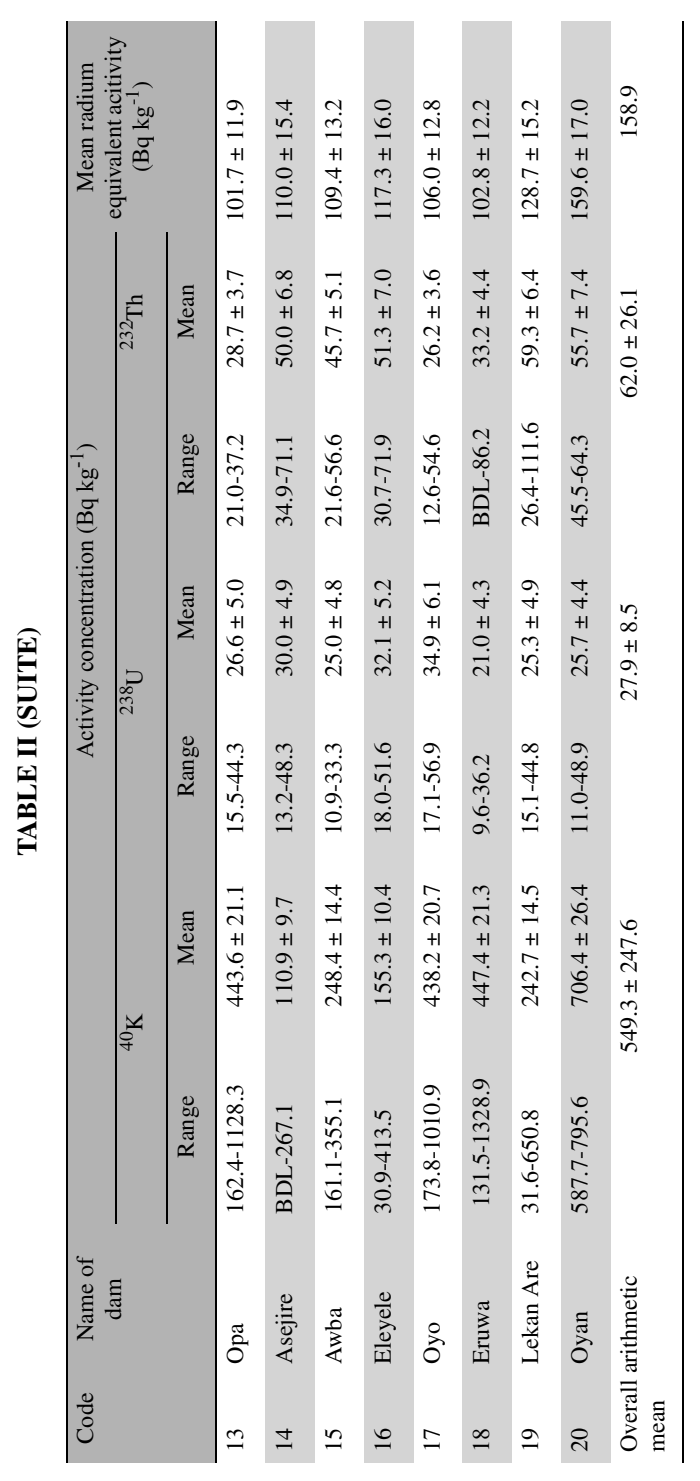




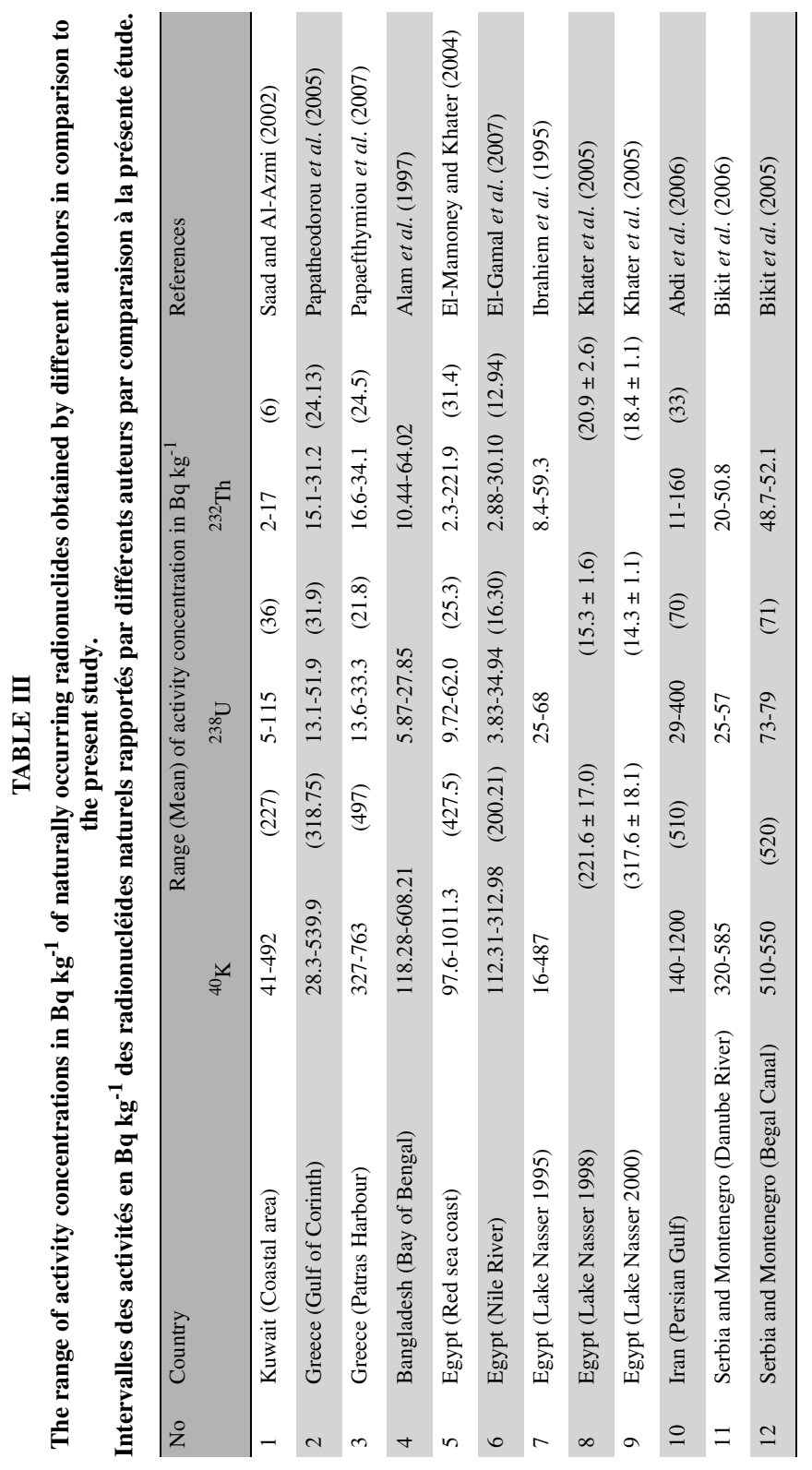


M.O. ISINKAYE, I.P. FARAI

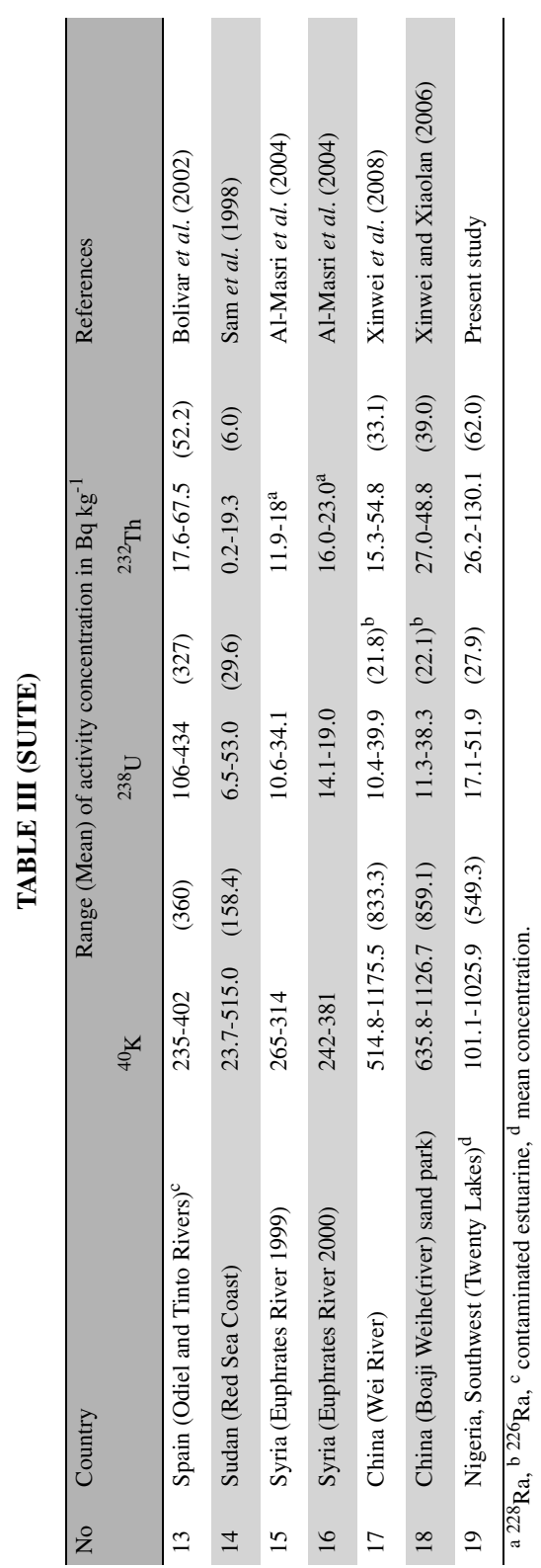




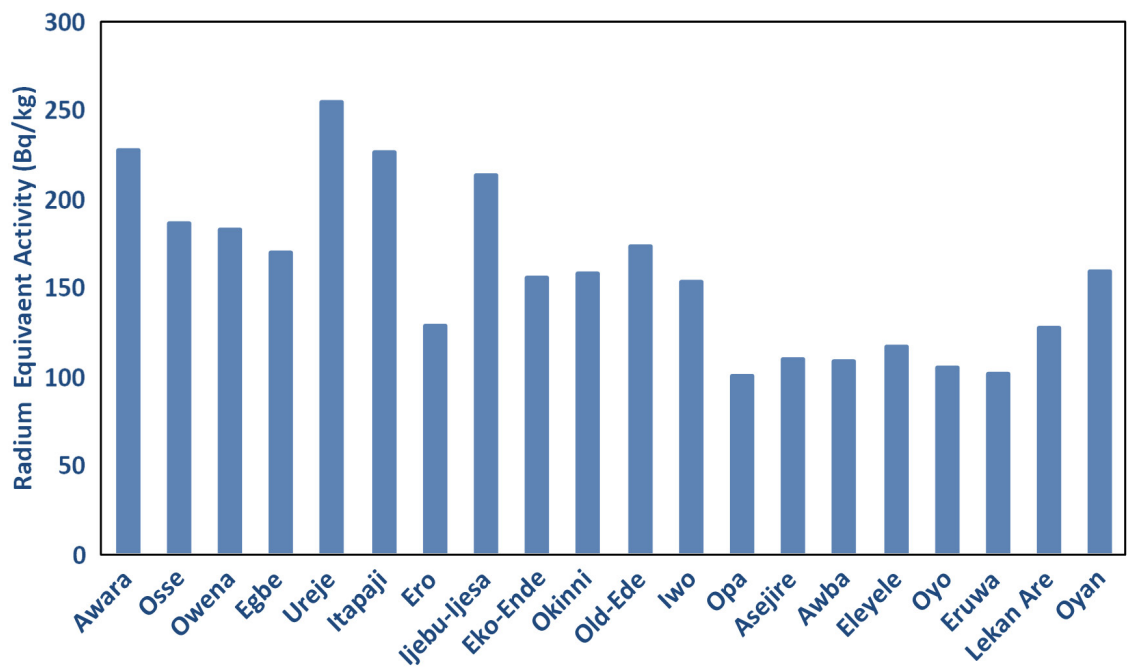

Figure 2 - Radium equivalent activity distribution in surface-water sediments from SW Nigeria.

La distribution de la radioactivité en équivalent radium dans les sédiments des eaux de ruissellement dans le sud-ouest nigérian.

radionuclides were combined in terms of radium equivalent activity $\left(R a_{e q}\right)$. This radium equivalent activity is a weighted sum of activities of the above named radionuclides. The estimation of $R a_{e q}$ is based on the assumptions that $10 \mathrm{~Bq} \mathrm{~kg}^{-1}$ of ${ }^{226} \mathrm{Ra}, 7 \mathrm{~Bq} \mathrm{~kg}^{-1}$ of ${ }^{232} \mathrm{Th}$ and $130 \mathrm{~Bq} \mathrm{~kg}^{-1}$ of ${ }^{40} \mathrm{~K}$ produce the same gamma dose rate (Turhan and Gunduz, 2007). The $R a_{e q}$ is defined as:

$$
R a_{e q}=C_{R a}+\frac{10}{7} C_{T h}+\frac{10}{130} C_{K}
$$

where $C_{R a}, C_{T h}$ and $C_{K}$ are the activity concentrations of ${ }^{226} \mathrm{Ra},{ }^{232} \mathrm{Th}$ and ${ }^{40} \mathrm{~K}$, respectively in $\mathrm{Bq} \mathrm{kg}^{-1}$. It has been assumed in this work that ${ }^{226} \mathrm{Ra}$ is in equilibrium with ${ }^{238} \mathrm{U}$.

The mean values of the radium equivalent activity and the associated uncertainties calculated (using Eq. (2)) for sediments in each of the dams are presented in Table II. Ureje dam in Ado-Ekiti has the highest mean radium equivalent activity value of $255.8 \pm 39.8 \mathrm{~Bq} \mathrm{~kg}^{-1}$ while the lowest value of $101.7 \pm$ $11.9 \mathrm{~Bq} \mathrm{~kg}^{-1}$ is observed in Opa dam located within the Obafemi Awolowo University (OAU) campus, Ile-Ife. Apart from two isolated cases in Awara dam (Ikare, Ondo State) and Okinni dam (Oba village, Osun State), none of the samples measured exhibited radium equivalent activity that exceeds $370 \mathrm{~Bq} \mathrm{~kg}^{-1}$, which is the maximum limit for safe use of the sediments (UNSCEAR, 1982). The variation of the radium equivalent activity in each of the dams is presented in Figure 2. The 
overall mean radium equivalent activity for the region has been estimated as 158.9 $\mathrm{Bq} \mathrm{kg}^{-1}$ from the mean radium equivalent activity for each of the dams as presented in Table II.

\section{Conclusion}

The distribution of natural radioactivity in the sediments of major surface-water dams in southwest Nigeria has been determined using $\gamma$-ray spectroscopy. The activity concentrations of ${ }^{40} \mathrm{~K},{ }^{238} \mathrm{U}$ and ${ }^{232} \mathrm{Th}$ obtained in this study are similar to those reported for rocks and soil of the area. It can therefore be concluded that the sediments analysed have potassium, uranium and thorium contents similar to those of soil and rocks in the area. The activity concentration of primordial radionuclides $\left({ }^{40} \mathrm{~K},{ }^{238} \mathrm{U}\right.$ and $\left.{ }^{232} \mathrm{Th}\right)$ obtained in sediments of surface-water dams investigated in this survey is typical of uncontaminated sediments in different parts of the world. Therefore the study area can be regarded as an area with normal level of natural background radiation. It can also be concluded from the values of mean radium equivalent activity obtained in each of the dams that the dose incurred from the sediments does not exceed the maximum limit for save use of the sediments. The values obtained in this work will serve as baseline data for the natural radioactivity distribution in sediments of surface-water dams and rivers of the study area.

\section{REFERENCES}

Abdi M.R., Faghihian H., Mostajaddavati M., Hasanzadch A., Kamali M. (2006) Distribution of natural radionuclides and hot points in Coasts of Hormozgan, Persian Gulf, Iran, J. Radioanal. Nucl. Chem. 270, 319-324.

Ajayi O.S. (2000) Distribution of natural radioactivity in rocks from Ikogosi-Ekiti, southwestern Nigeria and its radiological implications, Health Phys. 79, 192-195.

Alam M.N., Chowdhurry M.I., Kamal M., Ghose S., Mahmmod N., Matin A.K.M.A., Saikat S.Q. (1997) Radioactivity in sediments of the karnaphuli River estuary and the Bay of Bengal, Health Phys. 73, 385-387.

Al-Masri M.S., Byrakdar M.E., Mamish S., Al-Haleem M.A. (2004) Determination of natural radioactivity in Euphrates river, J. Radioanal. Nucl. Chem. 261, 349-355.

Bikit I., Varga E., Conkic Lj., Slivka J., Mrda D., Curcic S., Zikic-Todorovic N., Veskovic M. (2005) Radioactivity of the Bega sediment - case study of a contaminated canal, Appl. Radiat. Isot. 63, 261-266.

Bikit I., Slivka J., Veskovic M., Varga E., Zikic-Todorovic N., Mrda D., Forkapic S. (2006) Measurement of Danube Sediment radioactivity in Serbia and Montenegro using gamma ray spectrometry, Radiat. Meas. 41, 477- 481.

Bolivar J.P., Garcia-Tenorio R., Mas J.L., Vaca F. (2002) Radioactive impact in Sediments from an estuarine system affected by industrial wastes releases, Environ. Intern. 27, 639-645.

Chiozzi P., De Felice P., Fazio A., Pasquale V., Verdoya. M. (2000). Laboratory application of NaI(Tl) $\gamma$-ray spectrometry to studies of natural radioactivity in geophysics, Appl. Radiat. Isot. 53, 127 132. 
El-Gamal A., Nasr S., El-Taher A. (2007) Study of spatial distribution of natural radioactivity in the upper Egypt Nile River sediments, Radiat. Meas. 42, 457-465.

El-Mamoney M.H., Khater A.E.M. (2004) Environmental characterization and radio-ecological impacts of non-nuclear industries on the Red sea coast, J. Environ. Radioact. 73, 151-168.

Farai I.P., Ademola J.A. (2005) Radium equivalent activity concentrations in concrete building blocks in eight cities in southwestern Nigeria, J. Environ. Radioact. 79, 119-125.

Farai I.P., Jibiri N.N. (2000) Terrestrial gamma radiation dose level in Ibadan, Nigeria, Nig. J. Phys. 34, 195-199.

Fasasi M.K., Tchokossa P., Ojo J.O., Balogun F.A. (1999) Occurrence of natural radionuclides and fallout cesium-137 in dry season agricultural land of Southwestern Nigeria, J. Radioanal. Nucl. Chem. 240, 949-952.

Ibrahiem M.N., Shawky S., Amer H.A. (1995) Radioactivity levels in lake Nasser Sediments, Appl. Radiat. Isot. 46, 297-299.

IAEA (2003a) International Atomic Energy Agency, Collection and preparation of bottom sediment samples for analysis of radionuclides and trace elements, IAEA-TECDOC-1360, IAEA, Vienna, Austria.

IAEA (2003b) International Atomic Energy Agency, Guidelines for radioelement mapping using gamma ray spectrometry data, IAEA-TECDOC-1363, IAEA, Vienna, Austria.

Isinkaye M.O., Faweya E.B. (2006) Occurrence of natural radionuclides in refuse dump sites within the city of Ado-Ekiti, southwest Nigeria, Centr. Eur. J. Occ. Environ. Med. (CEJOEM) 12, 9-14.

Khater A.E.M., Ebaid Y.Y., El-Mongy S.A. (2005) Distribution pattern of natural radionuclides in lake Nasser bottom sediments, Intern. Congr. Ser. 1276, 405-406.

Papaefthymiou H., Papatheodorou G., Moustakli A., Christodoulou D., Geraga M. (2007) Natural radionuclides and ${ }^{137} \mathrm{Cs}$ distributions and their relationship with sedimentological processes in Patras Harbour, Greece, J. Environ. Radioact. 94, 55-74

Papatheodorou G., Papaefthymiou H., Maratou A., Ferentinos G. (2005) Natural radionuclides in bauxitic tailings (red-mud) in the Gulf of Corinth, Greece, Radioprotection 40, 549-555.

Saad H.R., Al-Azmi D. (2002) Radioactivity concentration in sediments and their correlation to the coastal structure in Kuwait, Appl. Radiat. Isot. 56, 991-997.

Sam A.K., Ahmad M.M.O., El-Khangi F.A., El-Nigumi Y.O., Holm E. (1998) Radioactivity in the Red Sea coastal environment of Sudan, Mar. Pollution Bull. 36, 19-26.

Singh S., Singh B., Kumar A. (2003) Natural radioactivity measurements in soil samples from Hamirpur district, Himachal Pradesh, India Radiat. Meas. 36, 547-549.

Turhan S., Gunduz Lu (2007) Determination of specific activity of ${ }^{226} \mathrm{Ra},{ }^{232} \mathrm{Th}$ and ${ }^{40} \mathrm{~K}$ for Assessment radiation hazards from Turkish pumice samples, J. Environ. Radioact. DOI: 10.1016/j.jenvrad.2007.08.022.

UNSCEAR (1982) United Nations Scientific Committee on Effects of Atomic Radiation, Sources and biological effects of ionizing radiation. United Nations, New York.

USDOE (1992) United State Departments of Energy: Procedure Manual 27th Ed. (revised) Environmental Measurement Laboratory HASL-300 P4.5.29.

USEPA (2007) United State Environmental Protection Agency. Technologically Enhanced Naturally Occurring Materials (TENORM): Drinking water treatment wastes, available at http://www.epa.gov/radiation/tenorm/drinking-water.html.

Xinwei L., Xiaolan Z. (2006) Measurement of natural radioactivity in sand samples collected from the Baoji Weihe sands park, China, Environ. Geol. 50, 977-982.

Xinwei L., Xiaolan Z., Fengling W. (2008) Natural radioactivity in sediment of Wei River, China, Environ. Geol. 53, 1483-1489. 